\title{
The Etiology of a Disorder (Dis-ease) and the Restoration of Order (Therapy). A Case of a Greek Belief Narrative Connected with Charms against Abdominal Diseases
}

\author{
Haralampos Passalis \\ University of Amsterdam, Dept. Modern Greek Studies, the Netherlands
}

\begin{abstract}
Although belief narratives and charms are regarded as two different folklore genres with different modes of transmission, performance and function, they are both in a constant dialectical relationship, yielding mutual feedback. One of the main forms of this interactive relationship concerns the etiology of a dis-ease (construction of a dis-order, i.e. belief narratives) and its therapeutic treatment (restoration of order, i.e. charms). This relationship between the cause of diseases and their treatment is clearly reflected in a Christian content belief narrative closely associated with incantations used to heal abdominal diseases. The basic personage embodying this belief narrative - registered in many and different areas of Greece is the figure of a monk or Christ himself, who, often disguised as a beggar, is hosted by a family. Violations of both religious norms associated with fasting and social ethics connected with accepted behaviour towards a guest have as a result the manifestation of an abdominal disease, which eventually the monk or Christ treats using an incantation. This article shows that the parallel analysis of legends and charms, where possible, is necessary since it can provide useful information, not only on the ways by which the charm text is produced and reproduced, but also on the position and status of the genre in the context of a wider folk religious system. Furthermore, it could contribute to the understanding of the charm text, without which the knowledge of the belief narrative is often incomprehensible, if not nonsensical.
\end{abstract}

Keywords: Greek charms, belief narratives, kind landlord, cunning landlady, monk, folk religious system, abdominal diseases

\section{INTRODUCTION}

Belief narratives or, according to Bascom (BASCOM 1965:4), legends and charms, constitute two different folklore genres with distinctive characteristics, ways of transmission, performance and function. The study of their relation is usually unexplored by researchers of both genres and is partially focused on one category of charms; narrative charms, also known as historiolae. This is not by accident, since this charm type is closely associated with the fact that the belief in the efficacy of magic lies on narratives and myths, comprised of descriptions of magical events that have occurred in the distant 
past and offer solutions to critical situations. Such narratives, however, do not appear as autonomous texts, independent of charms, but are closely related to charms and are in fact charms themselves. The myth of Osiri and Isida is a typical example of such a case, as it exists only as ritual verbal magic (FRANKFURTER 1995:472), along with the text known to researchers as the exorcism of Gello or Saint Sisinnius' prayer (PASSALIS 2014). Thus, they are myths of magic, as stated by Malinowski as well, and they exist only within the boundaries of magic (MALINOWSKI 1954:141). ${ }^{1}$ According to Nadel's arguments, this is due to the fact that magic is closely related to myth. Consequently, whenever a form of magical practice occurs, a mythology/legend simultaneously appears to justify and sustain the efficiency of magic (NADEL 1968:191).

While the narratives of the historiola type have been studied and attracted researchers' interest (PASSALIS 2011a; 2016:237-246), the relationship between charms and belief narratives remains unexplored. This is not surprising as the documented belief narratives connected with charms and the evidence we hold from recorded ethnographic data are, at least in Greece, rare and inadequate to promote a consistent study. Such scarcely recorded data in most cases comprise belief narratives which are connected to the first occurrence and transmission of charms, associating their origin with a sacred figure of high authority, thus validating their effectiveness ${ }^{2}$, or refer to restrictions of secrecy (transmission and performance), establishing their possession (factor of ownership) onto individuals responsible for their performance. ${ }^{3}$

The study of both genres, legends and charms, whenever and wherever possible, is considered vital and may contribute to a holistic approach, enlightening elements of a wider contextual frame within which both genres are produced and reproduced. The study of this interpretive frame is a basic prerequisite for the comprehension of the genres of folk oral literature. ${ }^{4}$ Regarding charm studies in particular, it could be said that since the aim of the verbal part of the genre is neither to transmit information nor narrate something, its analysis has to be based on a full comprehension of the consequences that the words allegedly have. Accordingly, their interpretation depends on their integration within a framework of cultural and symbolic relations. Those relationships include the connections between verbal magic and healing, the role of the supernatural world in human life, faith in the power of words, the beliefs of traditional culture regarding the order of things in the world along with the practices and methods used for their adjustment into this order.

1 Cf. Malinowski 1954:74; 1965:223 (primeval texts).

2 Cf. "According to the mythical system of verbal charm transmission, secret and sacred knowledge is passed down by word of mouth through the Virgin Mary, the saints or the angels (...) Moreover, in that type of narrative charm with a 'historiola', where a mythical event or encounter is described, the sacred person (Christ) is described as transmitting the verbal part orally to the saints" (PASSALIs 2011b:12).

3 Cf. It is worth mentioning also the case of one female charmer who refused to share the secret text of a charm against ants because, as she believed, "the moment she breathes her last, all the ants will gather around to feast on her body" (Passalis 2011b:9).

4 According to Foley 1992: 276: "To ignore the immanent context is to force situated words out of their natural significative setting - obviously a crippling and artistically violent reorientation". Cf. also the notion of "implicit meaning" (HerzFELD 1981:123), "traditional referentiality" (FolEY 1991:7, 38-60) and "expressive ecology" (FoLEy 2005:27). For the dependence of the effectiveness of the charms on contextual factors such as a) the power of the verbal part, b) the power of the performer c) the attitude of the ritual powers, d) the connection with religious and mythological tradition and e) the accompanied rituals, see LuDwig 1987:147. 


\section{THE CHARM AGAINST ABDOMINAL DISEASES}

The significance of examining charms and legends together, especially for the researchers of charms, is evident in the text documented in this study. It is a charm used against diseases of the abdominal area (pain in the intestines or abdomen) (See also IonAs 2007:A:41) which is widespread in various parts of Greece: Lefkada (KonTOMICHIs 1985:93), ${ }^{5}$ Paros (Stellas 2004:41-42), ${ }^{6}$ Megara (Vlachou 1959:548), ${ }^{7}$ Cyprus (Loukas 1974:54-55), ${ }^{8}$ Ksirochori (Rousias 1912-1913:499), ${ }^{9}$ Athens (Politis 1931:709); ${ }^{10}$ Crete (LenaKaKIS 2007:117). ${ }^{11}$ This type of charm is not only used against relevant human diseases but also, to a lesser extent, against animal ailments (KonTOMICHIS 1985:93; IonAS 2007:B:8587). Characteristic of the expanded use of this charm is the fact that in Cyprus 53 variants

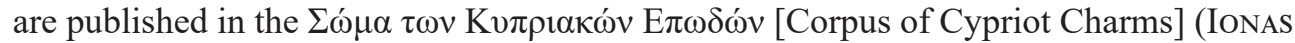
2007:A:42-44, B:63-87). ${ }^{12}$

It should be also noted that in the contextual framework of the charm, the use of a knife with a black handle is documented. The charmer waves the knife around, forming the mark of the cross (IonAS 2007:B:79, 81, 85) over the abdominal area of the sick person (IonAS 2007:B:63, 73, 78) or over the chest (IonAS 2007:B:63), simultaneously chanting the words of the verbal part. In other cases, a reed with three knobs is used, or a three- inch stick of styrax officinalis (IonAS 2007:B:62), or a piece of yew (IONAS 2007:B:86), while there are also narratives which indicate that during the charm, three olives and burnt bread are placed on a plate (IonAs 2007:B:67, 83). The use of the knife and of the olives is also documented and embedded in the narrative, as will be discussed later on. In Crete, as the charmer performs the ritual, he takes three pebbles, forms the sign of cross on the abdominal area and throws one behind the patient, the second towards the left and the third to the right (Christodoulakis 2011:201). There is no apparent differentiation in the ritual (IONAS 2007:B:62,85) whether performed on humans or animals, although there are instances when instead of a knife with a black handle a stick from a plant (styrax officinalis, $\sigma \tau \varepsilon \rho \alpha \tau \zeta$ í $\alpha$ ) or yew is used to thrice hit the

5 Lefkada: http://lefkadamia.blogspot.gr/2013/01/gia-ton-strofo.html (accessed November 6, 2019).

$6 T^{\prime} \alpha \nu \tau \varepsilon \rho о \varphi \alpha ́$ [for the pain in the intestines].

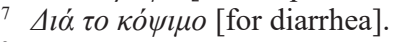

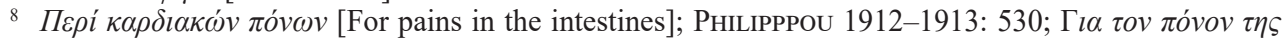

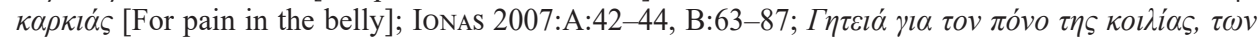

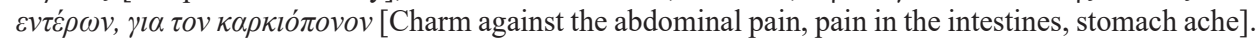

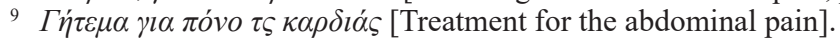

$10 \xi$ ǵ $\rho \tau \sigma l \sigma \varepsilon \kappa \omega \lambda l \kappa o ́ \pi o v o$ [Charm against the abdominal pain].

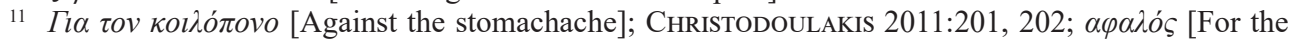
navel].

12 It seems that this type of charm - as well as the corresponding legend which will be discussed laterwith the expected variations in content and structure, is widespread and quite common in Central and South East Europe. According to Pócs 2014:895 (transl.): "Besides the Italian data, we also know of sporadic Romanian, Croatian and Serbian variants, which show that once this type of charm may well have been considerably more widespread in the Mediterranean region and Central and Eastern Europe. We are hoping that later exploration of the material in the Balkans will complete this currently incomplete picture." It is also worth mentioning that this charm type, according to Barbara Hillers' (HiLLERs 2019, 81-82), is well known and popular in Ireland as well as in Gaelic Scotland. 
sick animal (IonAs 2007:B:85, 86). In some cases, the combination of magical methods with the practical ones against the disease is documented: recitation of the charms along with drinking a glass of wine, which the patient consumes after the treatment (IonAS 2007:B:65), or applying oil or ethanol on the belly (IonAs 2007:B:72).

The typical structure for the charm of this type has two standard parts. ${ }^{13}$ The first one includes the objective element of the charm - objektives Element, according to Ohrt (OHRT 1935-1936. See also PASSALIS 2016:117) terminology - which appears in the form of a narrative. In the second part, the subjective element (subjektives Element) appears as a command on the personified pain in the abdominal area. Two of the most relatively complete versions of this type of charm, one from Cyprus and the other from Paros, are presented below:

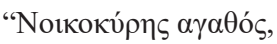

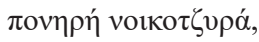 \\ $\lambda \alpha ́ \rho \delta o v ~ \varepsilon \mu \alpha \varepsilon i ́ p \varepsilon v \kappa \varepsilon v$,

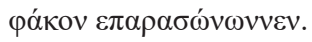

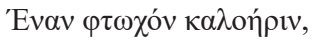

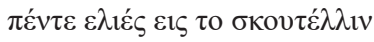

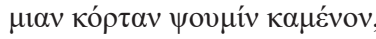

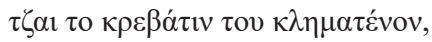

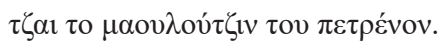

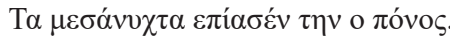

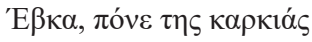

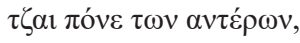

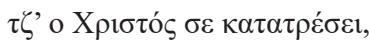

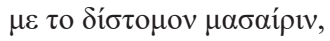

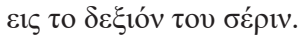

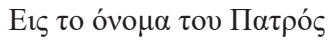

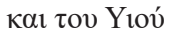

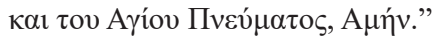 \\ (Cyprus, Ionas 2007:A:42)

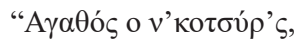

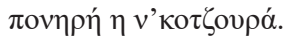

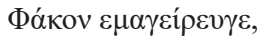

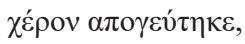 \\ $\chi \varepsilon \dot{\rho} \rho \mathrm{v} \varepsilon \xi \varepsilon \kappa \varepsilon \dot{v} \omega \sigma \varepsilon$.

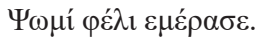 \\ $\tau \rho^{\prime} \alpha \lambda{ }^{\prime} \gamma \delta 1 \alpha \sigma \tau^{\prime} \alpha \pi \lambda \alpha \delta \delta^{\prime} v 1$.
}

\author{
[The landlord kind \\ the landlady cunning, \\ pork she cooked, \\ yet lentils she served. \\ A poor little monk, \\ five olives on the plate, \\ a piece of bread burnt, \\ his bed made of vine, \\ of stone his head bed had. \\ At midnight she felt pain. \\ Get out, pain in the belly \\ and pain in the guts, \\ Christ chases you \\ with a double edged knife \\ on his right hand. \\ In the name of the Father \\ and of the Son \\ and of the Holy Spirit. Amen.] \\ [The landlord kind, \\ the cunning lady, \\ Lentils she cooked, \\ pork she ate \\ and defecated pork. \\ A slice of bread she offered. \\ three small olives on the plate.
}

13 Cf. for this type of charm Pócs 2014:895 (transl.): "The specific action narrated in the charm (looking for shelter, punishing the heartless host and then curing them) sets it apart from all other types of epic charms recording encounters between the healer and the sufferer, even though one of the cores of the narrative (one holy person asks the other to perform healing) fits in well with what constitutes the second group of 'encounters' in Ferdinand Ohrt's own system which he defined by the title Encounter with the healer". 


\begin{tabular}{|c|c|}
\hline 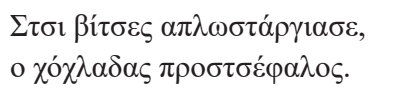 & $\begin{array}{l}\text { On sticks she lay, } \\
\text { the pillow made of stone. }\end{array}$ \\
\hline 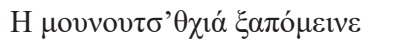 & The bed in the guest house unused \\
\hline 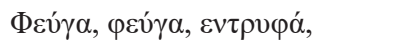 & Go away, pain from the belly, \\
\hline 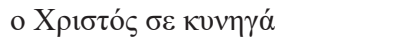 & Christ chases you \\
\hline 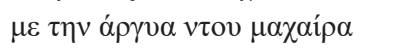 & with his silver knife \\
\hline 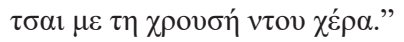 & and his golden hand.] \\
\hline
\end{tabular}

The objective element begins with a reference to a group of people, including two figures: the man and the lady of a house. The adjectives accompanying the two figures reflect the difference between them. On the one hand, there is the man of the house, who in most cases is characterized as 'kind/naive/benevolent' ( $\alpha \gamma \alpha \theta$ ós) (LouKAS 1974:54; IonAS 2007:A:42, B:63, 66-71, 73, 74-78, 80-84, 86; Stellas 2004:41; Christodoulakis 2011:201-202; Politis 1931:7; Rousias 1912-1913:49; VlaChou 1959:548) and in

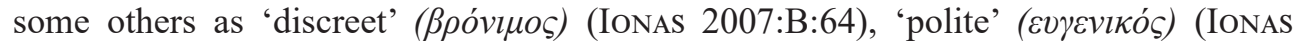
2007:B:72) or 'sensible' ( $\gamma v \omega \sigma \tau \imath \kappa o ́ s)$ (LenaKaKis 2007:117). On the other hand, there is the landlady who is characterized in most cases as 'cunning' ( $\pi \circ \eta \eta \eta \eta$ ) (LoukAs 1974:54; IONAS 2007:A:42, 43, B:63-66, 69, 70, 72-78, 80, 81-84, 86; Stellas 2004:41; LENAKAKIS 2007:117; VlaChOU 1959:548; LouKaS 1974:54-55; Rousias 19121913:49; Politis 1931:70) and in one case as 'insidious' (' $\pi i \beta$ ' 2011:201-202). There are also cases in which the two figures do not differ and both are described negatively (cunning the landlord, cunning the landlady) ${ }^{14}$ or both positively (the landlord kind, the landlady kind). ${ }^{15}$ Nevertheless, those instances are rare and are due to the expected modifications of the text during the verbal transmission and performance of this type of charm. It is therefore noteworthy that there is no variation including a reverse of roles, that is to say the man of the house is cunning and the lady kind.

What directly follows the presentation of the hosts is the reference to activities related to cooking and offering of food. The food, on one hand, is associated with affluence and is cooked on special occasions - pork, rabbit/hare or meat in general - and is, on the other hand, connected with common, everyday food in agricultural regions, such as legumes, lentils or beads:

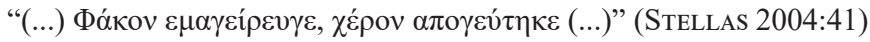

[lentils she cooked, pork she ate and she was pleased];

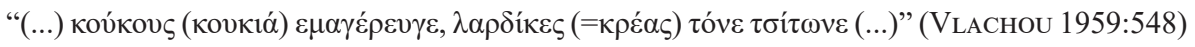

[beans she cooked, meat she defecated];

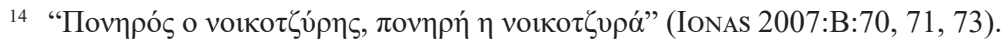

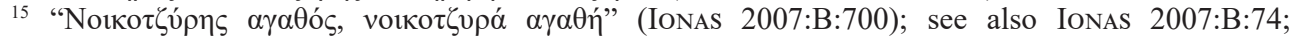
KONTOMICHIS 1985:93. 


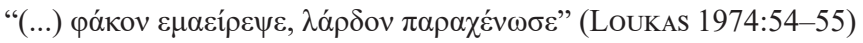

[lentils she cooked, salty pork she defecated];

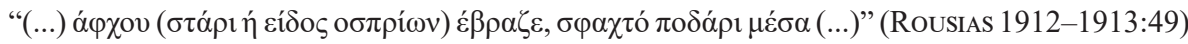

[grains or type of legumes she boiled, slaughtered animal leg inside];

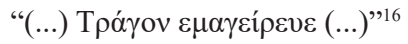

[male goat she cooked];

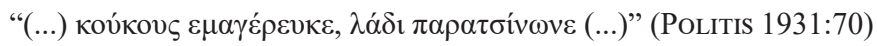

[beans she cooked, oil she defecated];

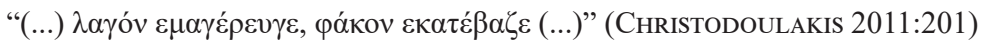

[hare she cooked, lentils she defecated].

At the same time, those types of food are related to the dietary restrictions and prohibitions (fasting) connected with the religious system that determines dietary habits.

What follows the report of food is the third dramatic persona of the narrative, presented as a monk. This person undertakes the role of a victim. Distinctively, the monk is always portrayed as poor - with both meanings of the term 'poor fellow' and 'has not got the basics to live' (IonAs 2007:A:42, 43, B:64, 66, 71-75, 77, 78, 81, 83, 84, 86), while

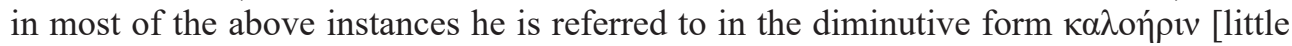
monk] (IonAs 2007:A:42, B:62, 66, 71, 73, 75-78, 80, 83, 85, 86). It is worth mentioning that the figure of a monk is mainly found in charms from Cyprus, whereas there is no report of this persona in charms originated in other areas of Greece (CHRISTODOULAKIS 2011:201; LenakaKis 2007:117; Politis 1931:70; Rousias 1912-1913:49; Stellas 2004:41, 42; KonTOMichis 1985:93).

Following the presentation of the monk, there is a reference to another list of food offered to him (IoNAS 2007:B:63). In almost all cases, this list includes: two (LENAKAKIS 2007:117), three (Rousias 1912-1913:49; IONAS 2007:B:64, 67; Christodoulakis 2011:201-202) or in most cases five olives (LouKAs 1974:54; PHILIPPOU 1912-1913:530; IONAS 2007:A:42, 43, B:63-86; VLACHOU 1959:548). It is often enriched with the listing of other types of food that all belong to the category of trivial or even ruined food:

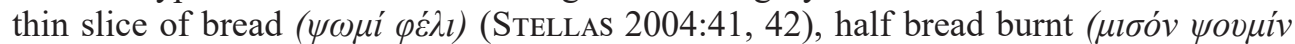

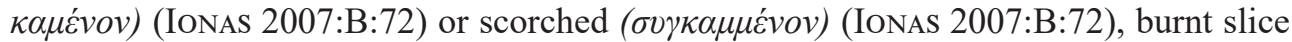

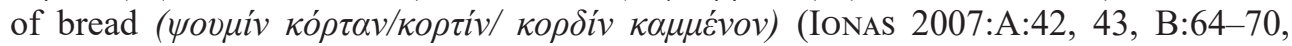

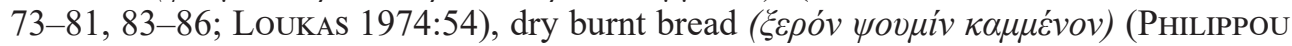

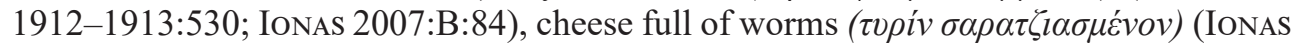

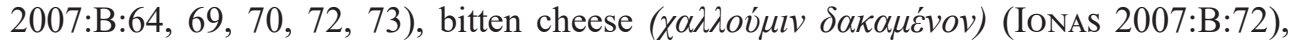

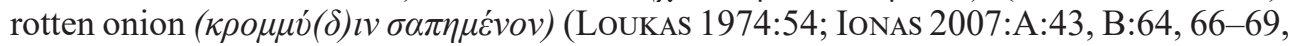

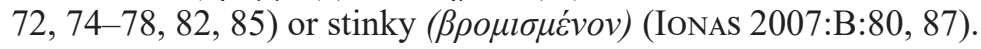

\footnotetext{
16 http://lefkadamia.blogspot.gr/2013/01/gia-ton-strofo.html (accessed November 6, 2019).
} 
Subsequent is an extra list which does not include food, but sleeping conditions. These conditions appear to be demeaning and insulting towards the guest, whom

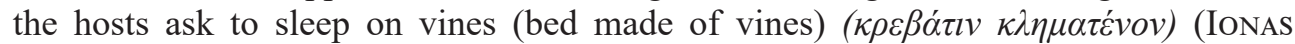

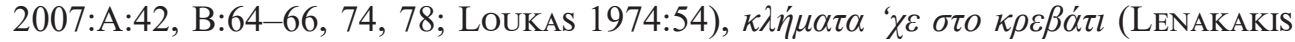

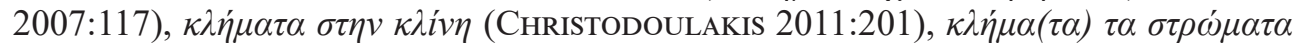

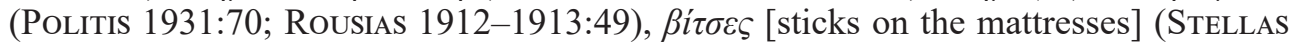
2004:41)) or on the ground ( $\chi \omega \mu \alpha \tau \dot{v} v o v)$ (IonAs 2007:B:70, 71, 73, 75, 86) or the

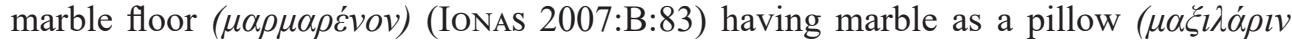

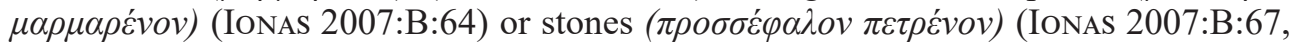

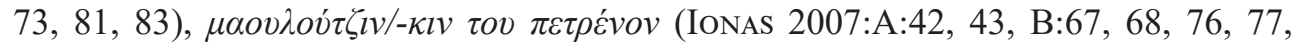

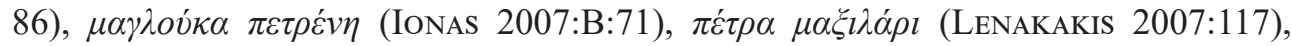

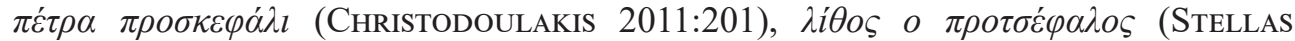

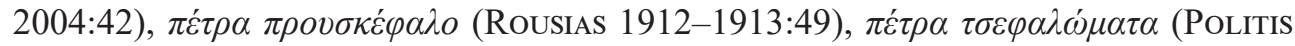

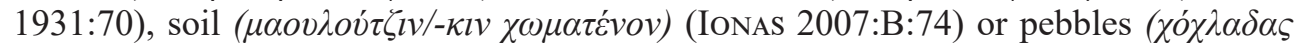
$\pi \rho o \sigma \tau \sigma \varepsilon ́ \varphi \alpha \lambda o \varsigma)$ (Stellas 2004:41) and cover himself with a cover made of vines

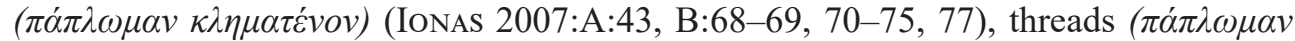

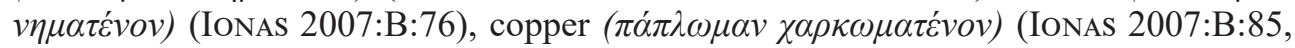

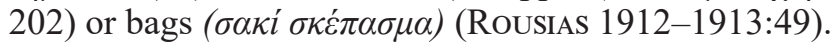

The subjective element (subjektives Element) in the second part of the charm is presented as a command addressed to the personified source of pain and expressed through the imperative form of two basic verbs: get out ( $\beta \gamma \varepsilon \varsigma)$ and go away/leave ( $\left.\varphi v \gamma_{\gamma}\right)$. This command is often enhanced by an additional element, which involves the sacred power. Christ is presented to chase the personified disease: Christ chases away the pain in the intestines holding a silver knife in his right hand.

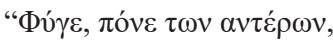

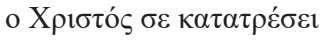

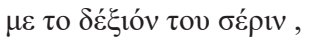

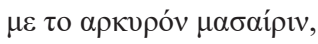

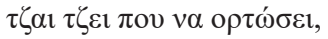
$\tau \zeta \varepsilon 1 \alpha \mu \alpha i ́$ $\sigma \varepsilon \kappa \alpha \tau \alpha \kappa o ́ \beta \kappa \varepsilon เ \varsigma^{\prime \prime}$ (IONAS 2007:B:64)
}

[Leave, pain in the intestines,

Christ chases you

with his right hand,

with the silver knife,

and when he reaches you,

instantly, he cuts you into pieces.]

There are alterations and modifications among variants in this part as well. These

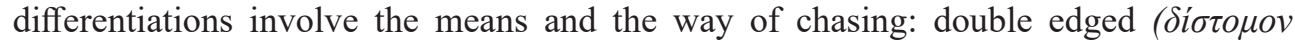
$\mu \alpha \chi \alpha i \rho l v \kappa \alpha \iota \mu \varepsilon \tau \eta v \chi \rho v \sigma \eta ́ v \tau \eta v \lambda o ́ \gamma \chi \eta \nu$ ) [with two edges knife and golden spear] (IonAS

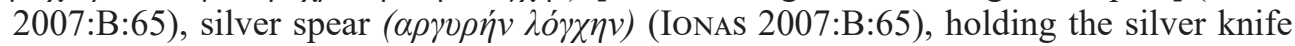

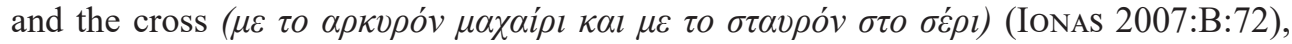

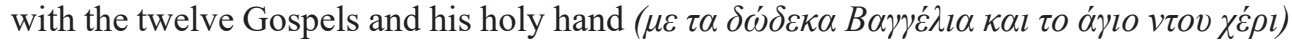
(LeNAKAKIs 2007:117), with the leg and the hand and the silver knife $(\mu \varepsilon \tau o v \pi o ́ \delta \alpha \mu \varepsilon$ $\tau \eta v \sigma \varepsilon \dot{\varepsilon} \alpha \nu, \tau \zeta \alpha l \mu \varepsilon \tau \eta \alpha \rho \gamma v \rho \eta \dot{v} \mu \alpha \sigma \alpha i \rho \alpha v)$ (IonAs 2007:B:82), with his silver knife and his

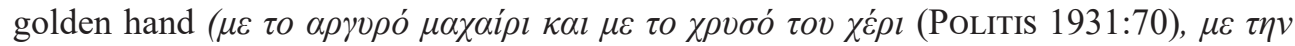

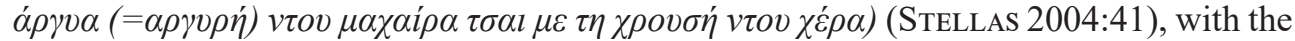

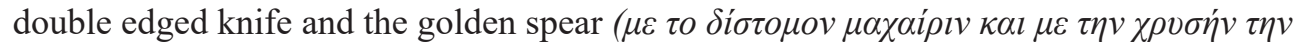
$\lambda o ́ \gamma \chi \eta v)$ (LouKAs 1974:54-55), with the silver knife and his right hand ( $\mu \varepsilon \tau \eta v \alpha \rho \gamma v \rho \dot{\eta}$

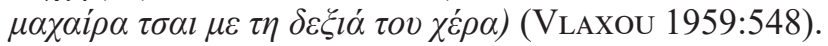


The charm ends with a typical phrase which is in the form of a) reference to the Holy Trinity ${ }_{17} \mathrm{~b}$ ) a simile "just like ....so", ${ }^{18}$ or more rarely c) a combination of $\mathrm{a}$ and $\mathrm{b}$ (IONAS 2007:B:84).

The documented material and the comparative study of the variations allow us to perceive a minimum of textual meaning, which is though inadequate to accomplish a satisfactory comprehension of the context in the charms of this type. Furthermore many parts of the charm are ambiguous and require further clarification. Why is the landlord characterized as kind/naïve whereas the landlady is cunning? What is the purpose of naming certain types of food and referring to sleeping conditions, and also how are these elements connected with narrative? What is the relationship between the monk and the main characters? As it has already been mentioned, the reference to the monk is sometimes omitted. The textual relation between the objective and the subjective element of narration, which includes the command of removing pain, is loose, not to mention absent, while in some charms it has been omitted (PHILIPOU 1912-1913:530; Rousias 1912-1913:49; Kontomichis 1985:93; Ionas 2007:B:68). It is not evident

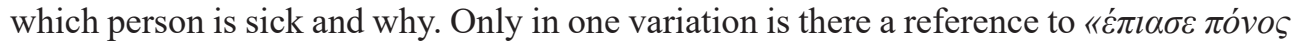

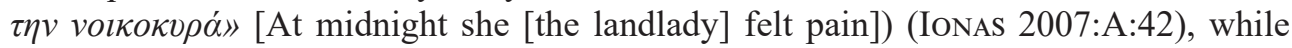

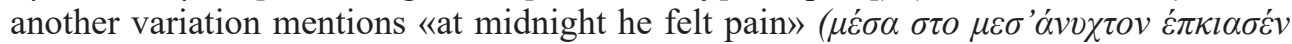

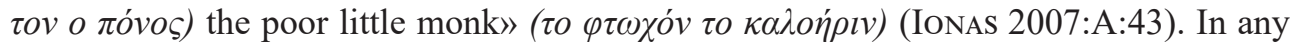
case, it is evident that we have to deal with an elliptic text, partly readable and in some variations totally illegible or even incomprehensible (IoNAs 2007:B:77).

\section{THE BELIEF NARRATIVE}

The parallel analysis of the charm examined here and the belief narrative with which it is related responds to all the previous questions. The belief narrative, which allows the decoding of the obscure and illegible parts of the charm, is encountered in different areas of Greece: Cyprus (Ionas 2007:A:42), Athens (Politis 1931:70), Lefkada, ${ }^{19}$ Paros (Stellas 2004:41-42), Megara (Vlachou 1959:548-549), Cyprus (LoukaS 1974:54-55; PhILIPPOU 1912-1913:530), Ksirohori (Rousias 1912-1913:49), Crete (Anagnostakis 1932-1933:4; Politis 1931:71 note, Lenakakis 2007:117). ${ }^{20}$ The number of this particular narrative, although inadequate, is indicative of its popularity and lets us study the relationship between charm and legend. It is certain that further research in archives will increase this number considerably.

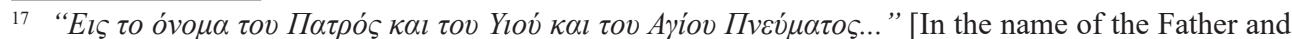
of the Son and of the Holy Spirit] (IonAs 2007:B:64, 65, 68, 69, 70-86).

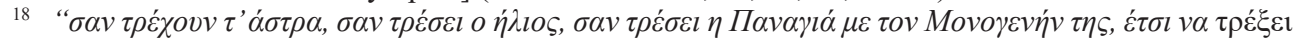

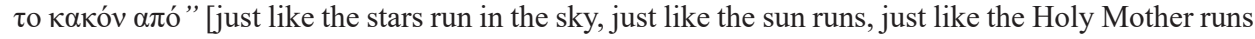

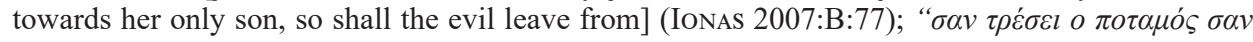

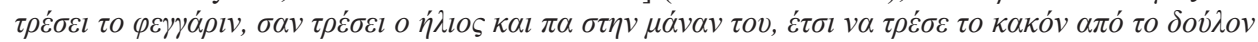
$\tau o v \Theta \varepsilon o v^{\prime} . .(\tau \dot{\alpha} \delta \varepsilon)$ ) " [just like the river runs, just like the moon runs, just like the sun runs and goes to his mother, so shall the evil go away from the servant of God] (IoNAs 2007:B:80).

19 http://lefkadamia.blogspot.gr/2013/01/gia-ton-strofo.html (accessed November 6, 2019).

20 The same narrative, despite its relation to a different charm, is also documented on the island of Milos (Vichos 1960), and Kea (SPYRIDAKIs 1960). 
It should be noted that the available documented narratives feature variations and modifications from area to area, as far as their extent and specific elements of their text are concerned. In all cases, however, the legends follow a consistent structure that can be clearly understood. The following texts, one of Megara and one from Crete, are two of the most representative variants;

“Mı

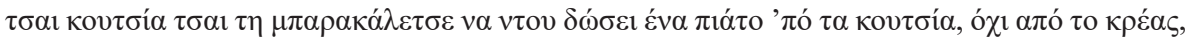

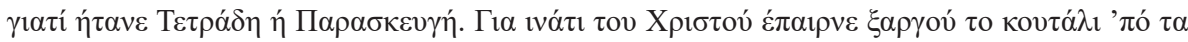

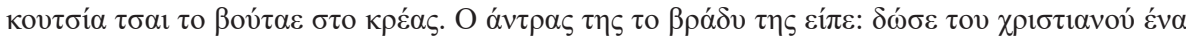

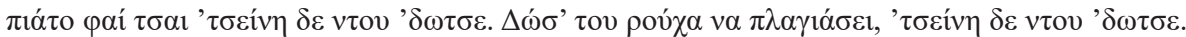

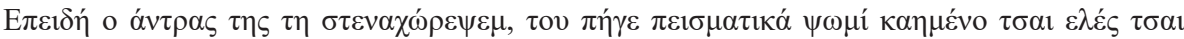

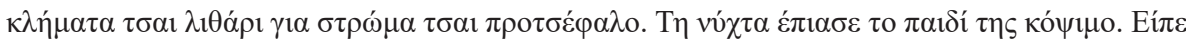

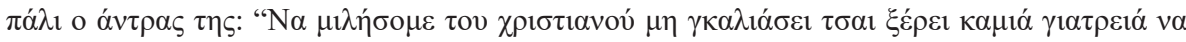

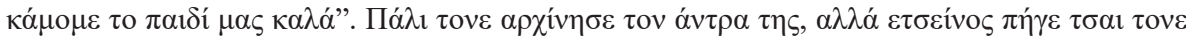

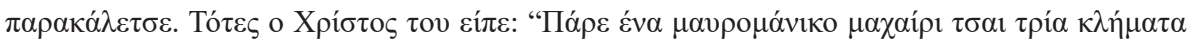

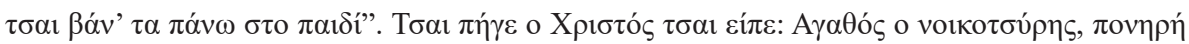

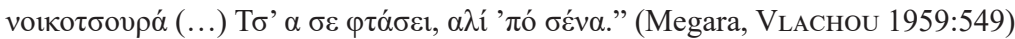

[Christ once visited a house as a beggar. As the housewife was boiling broad beans, he begged for a broad beans plate, not meat, as it was Wednesday or Friday. Her stubbornness made her dip the spoon from the broad beans to the meat on purpose. Her husband told her in the evening: "Give the poor man some food" but she did not. "Give him clothes to fall in bed", but she didn't. As her husband made her feel angry, she deliberately gave him burnt bread with olives and vines as a mattress and stone as a bed head. During the night, her kid suffered from diarrhea. Her husband said again: "Let's talk to the poor man in case he knows any treatment to heal our kid". Despite her repeatedly grumbling to her husband, he begged him (the beggar). Then Christ said; "Virtuous the landlord, cunning the housewife (...) and when Christ comes to the point where you are, alas"]

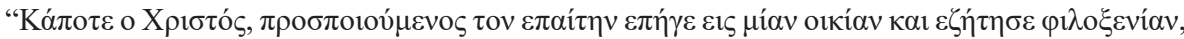

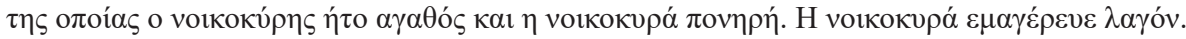

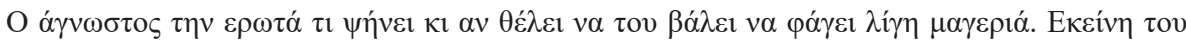

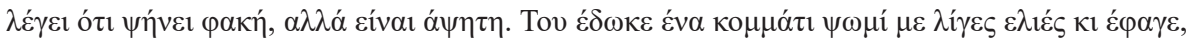

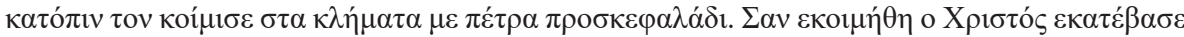

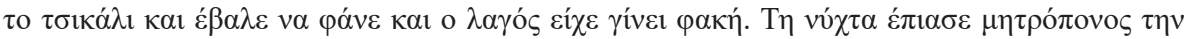

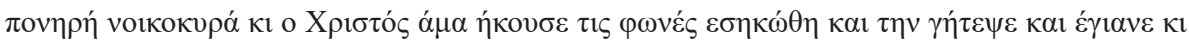

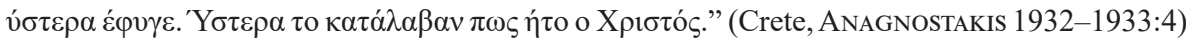
[Once Christ, pretending to be a beggar, asked to be hosted in a house where the landlord was virtuous and the housewife was cunning. The housewife was cooking a hare. The stranger asked her what she was roasting and if she would like to offer him some homemade food. She told him that she was cooking lentils soup, but it was still raw. He ate a piece of bread with some olives that she gave him; then he was offered to sleep on the vines with a bed head of stone. When Christ fell asleep, she laid the table, but the hare had turned into lentils soup. During the night, the cunning housewife suffered from stomach ache and when Christ heard her cry, he got up, healed her and then he left. Later on, they realized that he was Christ himself.] 
Almost all the variants belong to the same framework, with minor changes which do not disrupt the basic pattern. The characters are classified into two groups. The first one includes the landlord and the housewife and the second group includes the guest, while in some variants there is also the sick family child (VICHOS 1960). In most variants, however, the disease afflicts the housewife herself rather than the child:

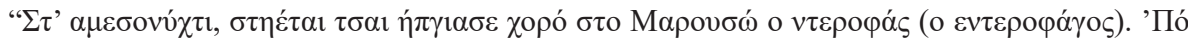

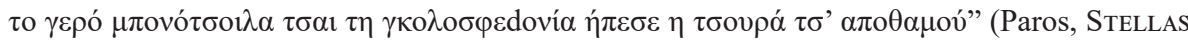
2004:41)

[At midnight, Marouso was afflicted by an awful and terrible pain. The severe pain almost drove the lady to death]

There is also a variant from Crete, where the sick person is the landlord:

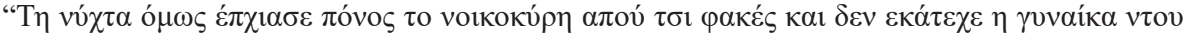

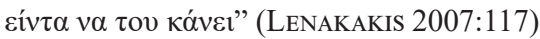

[During the night, the landlord suffered from pain because of the lentils soup and his wife had no idea what to do]
\end{abstract}

These legends clarify all the illegible elements of the aforementioned charm. Firstly, they define the characters appearing in the majority of the independent charms: the benign landlord, the cunning housewife and the poor monk. These references are sufficiently explained in the main narrative, while in the charms they are not. The cunningness and the negative description of the housewife is related to the fact that she usually withholds the main meal of the family ${ }^{21}$ and offers the guest some poor quality food, ranging from a humiliating meal (lentils soup, fava bean soup, three or five olives on the plate etc.) to even letting him starve in some variations.

The rude behaviour of the housewife totally contradicts the kind behaviour of her husband:

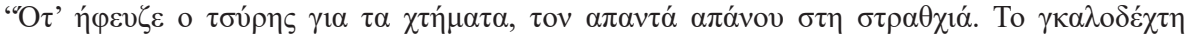

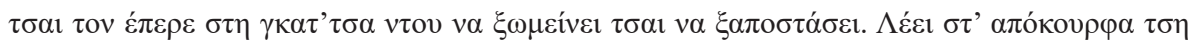

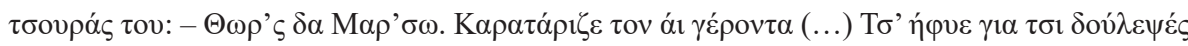 $v \tau$ '” (Paros, Stellas 2004:41)

[When the landlord set off for his land, he came across him. He welcomed him and took him home to rest and if he wanted, he could even stay overnight. He secretly asks his wife: - Look Mar'so. Take care of the holy old man (...) and he left for his work]

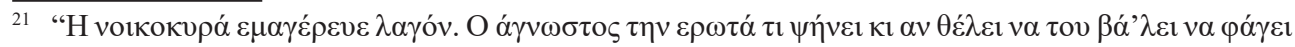

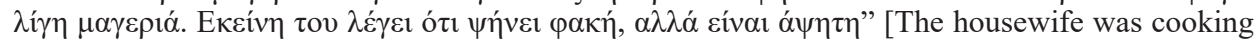
hare. The stranger asked what she was cooking and if she was willing to offer him a cooked meal. She told him that she was cooking lentils soup, but it was not ready yet] (ANAGNOSTAKIS 1932-1933:4). 
In many variants the husband condemns his wife's rude and offensive behaviour:

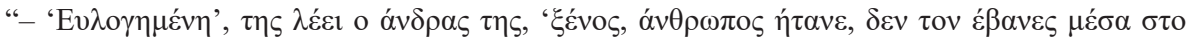

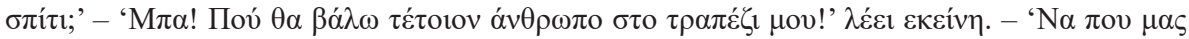

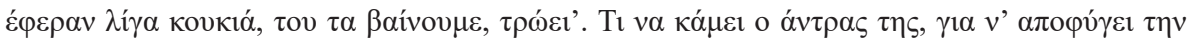

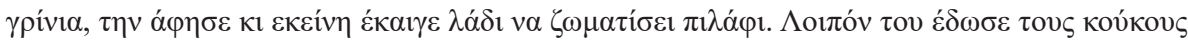

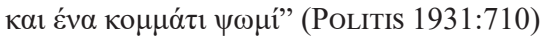

[- "Blessed you" her husband tells her, "he was a stranger, didn't you host him?" - "No way! How can I dine with such a man!" she replies. - "Here are some fava beans that we were given, we will offer him and he will eat them". Her husband left her, in order to avoid her moaning, while she was heating oil to cook pilaf. So, she offered him the fava beans and a piece of bread]

The positive and kind behaviour of the husband as well as the negative, rude behaviour of his wife is documented not only in the provision of food but also by the overnight conditions which are offered to the guest. The following excerpts of some variants certify and demonstrate not only the negative behaviour of the wife but also the objection of her husband, who finally does not manage to impose his opinion on her:

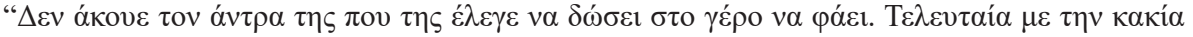

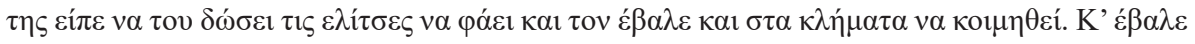

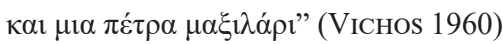

[She disobeyed her husband, who told her to give the old man some food. Finally, full of evil, she decided to give him olives to eat and to sleep on the vines with a stone bed head]

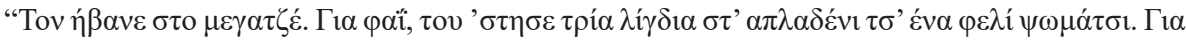

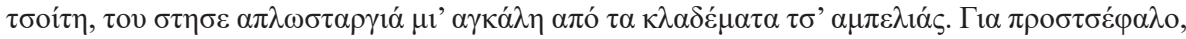

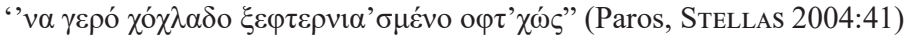

[She offered him the warehouse (to sleep). As for food, she gave him three small olives on a small plate and a little slice of bread. (As for bed) she spread an armful of vine sticks. As for bed head, a big pebble, luckily without any edges and points!]
}

The aforementioned quotations sufficiently explain and clarify illegible parts of the charms, concerning not only food but also overnight and survival conditions.

The consequence and punishment for such behaviour is the appearance of a disease which is related, not at all randomly, to food consumption, and it concerns abdominal problems, pain or even diarrhea. However, this disease does not afflict the starving guest, but a family member and mainly the housewife. The guest is asked to cure this disease because of the intervention of the husband, who addresses him in order to provide help. This is the third character, which appears in most charms in the form of a poor monk:

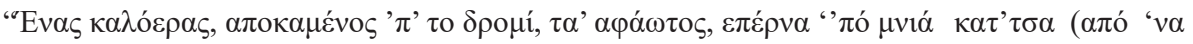

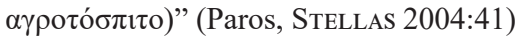

[A monk, tired of walking and hungry, passed by the farmhouse] 
The role and the function of the guest are explicitly clarified in the legends where he appears, not only as a monk, but often in the form of a poor man or a beggar, identified with Christ:

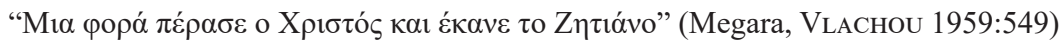

[Christ once came by as a beggar]

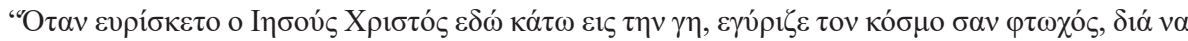

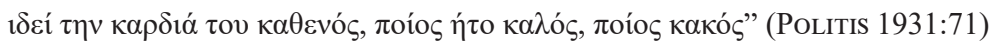

[When Jesus Christ was on Earth, he wandered around the world as a poor man, in order to have an insight into everyone's heart, those who were kind, those who were evil]

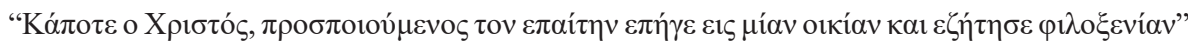
(ANAGNOSTAKIs 1932-1933:49)

[Once Christ, pretending to be a beggar, visited a house and asked to be hosted, the landlord was kind and the housewife was cunning]

The identification of the poor monk, beggar and stranger with Christ, is not random. The belief that a holy person, mainly Christ, can appear in the form of a beggar, poor man etc. in order to check the people's faith is quite popular in the context of the folk religious system. The following ethnographic testimonies from Paros are characteristic of the popularity of this belief, closely related to legend:

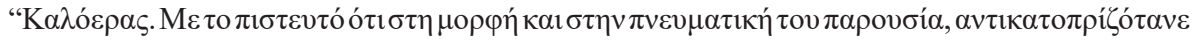

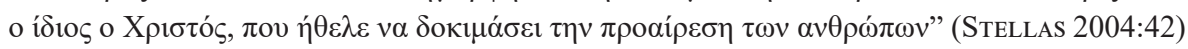
[Monk. Believing that Christ himself was reflected in the form and the spiritual presence of a monk, aiming at testing people's intention.]

\section{ETIOLOGY AND THERAPY OF DISEASE}

The aforementioned narratives belong to the category of "legends", according to the definition of this folklore genre of the American folklorist William Bascom (BASCOM 1965:3). One of the basic characteristics of legends is that they were believed to be real by people who lived in so-called traditional societies. Nevertheless, it is obvious that the belief narrative discussed here, along with other similar narratives, belongs to the sphere of myth; and as we all know, myths use symbolic and allegorical language, not literal. The American mythologist Joseph Campbell (CAMPBell 1988:22-23), who is predominantly a researcher of myth and its function, refers to the "sociological function" of myths, which aims at validating and enhancing certain social norms and statu quo, and to the "pedagogical function", which focuses on teaching a specific human way of life. Therefore, in a large number of folk narratives we observe that people's fear of violations of socially acceptable rules is indirectly expressed, though, in terms of its general structure, an allegorical narrative.

Knowing the specific belief narrative is quite useful since it not only facilitates sufficient comprehension of the charms, but also associates the text with a network of contextual 
elements that are connected to the wider cultural frame within which the incantations are produced and reproduced. The belief narratives integrate the cause of the disease. This relies on violating taboos and rules of ethical conduct, which aims at avoiding potential deviant behaviour as well as at enhancing social solidarity towards people in a crucial situation, whether it is about foreigners or socially and financially disadvantaged groups. This mechanism is based on and supported by a traditional religious cosmology that associates these groups with a sacred figure of high authority, Christ himself.

The narrative under examination also includes customs and rules which refer to dietary taboos. Such dietary prohibitions are connected to avoiding certain kinds of food, especially during days of fast as defined by the religious system of traditional Greek society, like Wednesday and Friday, when consumption of meat ought to be avoided:

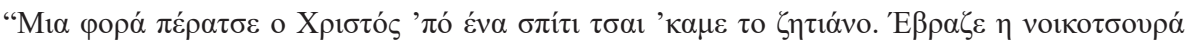

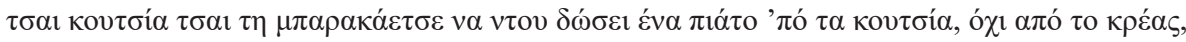

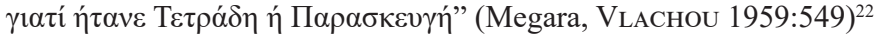

[Once, Christ came by a house pretending to be a beggar. The lady of the house was cooking broad beans so he asked her to offer him a plate of broad beans, not of meat, because it was Wednesday or Friday]
}

The violation of those restrictions in combination with the attempt to deceive the monk is considered to be a sin and is punished by turning the meat into lentils:

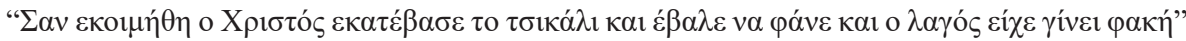
(ANAGNOSTAKIS 1932-1933:40)

[When Christ fell asleep and she served food, hare had been turned into lentils]

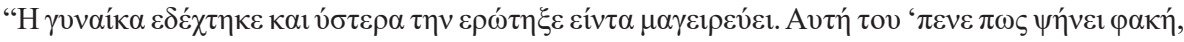

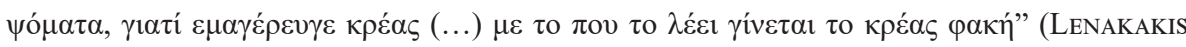
2007:117)

[The woman agreed and then he asked her what she was cooking. She told him she was cooking lentils, but she lied to him, because she was cooking meat (...) the minute she told the lie the meat turned into lentils]

Her being sick is the ultimate punishment for her negative behaviour, which is considered to be a sin.

Some collectors of folkloric data are familiar with this belief narrative and explain the incantation by stating: "The charm (...) is based on the following myth. Christ disguised as monk requested accommodation from a priest whose wife was capricious and mean/ evil. She took no care of Christ and as a result that very night she suffered from colic. They asked Christ to cure her and so he did. Afterwards, Christ disappeared and it was then that the priest realized he was not a common foreigner, but Christ himself." (IonAS 2007:A:42 (transl.) "The chant derived from this legend. Once Christ, pretending to be a beggar (...). Then they realized it was Christ." (Crete, ANAGNOSTASKIS 1932-1933:40

\footnotetext{
22 A similar case is documented in Stellas 2004:41.
} 
(transl.)) It is also worth noting that a folklorist from Paros characteristically calls this kind of collected material a mixed genre, which does not follow the restrictions of transmission and the performance of charms (STELLAS 2004:42). That is to say, it neither requires special users nor a secret transmission and performance. ${ }^{23}$

Nonetheless, we observe a considerable amount of independent charms documented without a supplementary comment nor a reference to the belief narrative they associate with. These independent charms maintain all the basic traits of the genre, the restrictions on transmission and performance, and are used as treatment for the diseases in the abdomen area. It is still uncertain whether the absence of a correlation is due to insufficient documentation of the available folk texts or there is indeed ignorance of this narrative. It seems, however, that the specific incantation follows a second method of transmission: it is based on a legend, but in the process it becomes independent and follows the rules and principles that apply to the transmission and performance of charms. The illegibility of the text does not seem to worry researchers since nonsensical words and elliptic content are considered to be one of the main characteristics of the verbal magic. Besides, contrary to legends, comprehension of the charm is irrelevant to its assumed efficacy (Passalis 2016:218-20).

\section{CONCLUSIONS}

The comprehension and legibility of the incantations examined in this paper would not be satisfactory without the knowledge of corresponding belief narrative to which they are closely connected. Such knowledge clarifies the verbal part of the charm, turning it from an illegible and inconsistent text into a comprehensive, readable one. Despite being quite different genres, the belief narratives and the charms are interrelated here in a functional, supplementary way. What is documented in the legend is the explanatory and justifiable model which clarifies the cause of the disease, rooted in the violation of rules. Hence, it is not only an explanatory model for provoking a disease, but also an example of warning against potential deviant behaviour. In this way, the social norms connected with acceptable behaviour towards guests are validated, thus reinforcing social solidarity towards people in need, such as the foreigners, the poor and beggars. The charm thus constitutes the therapeutic method of restoring a disorder caused by the violation of norms connected with the acceptable religious behaviour. What we see here is that charm and the belief narrative coexist as a whole entity that is functional within the framework of traditional Greek culture. Are there other cases of charms connected to belief narratives in such an integrated way yet to be examined? Further study could probably shed light and contribute to a more holistic approach to both genres.

23 The relation and the close connection between charm and the relevant legend have also been noted by other researchers of European charm. Cf. Pócs 2014:895 (transl.): "However, due to further motifs of the historiola, this charm shows connections mostly with other genres, primarily with legends that represent Christ and St. Peter wandering on earth. In her relevant analysis, Tekla Dömötör traces this charm back to an Egyptian magical text: the goddess Isis walks on Earth and a rich woman refuses to give her shelter. Isis strikes her child down with a disease, but then takes pity on the child and teaches the mother a healing charm. Dömötör lists parallels from Southern Italy based on Ernesto de Martino, to which we may add further data from Sicily". 


\section{ACKNOWLEDGEMENTS}

I would like to express my gratitude to emeritus professor Eva Pocs for providing me the chapter XVIII. Jó ember és gonosz asszony. "Gyékényágy, kőpárna” A good man and an evil woman (Bed of wattle, pillow of rock)], of the still unpublished English translation of her book Ráolvasások. Gyüjtemény legújabb korból (1851-2012) [Charms. Collection from the Modern Period (1851-2012)]. Budapest: Balassi Kiadó 2014 (pp. 895-914). The comparative study of the this type of text confirms the dissemination of this legendcharm in the area of Central and South-East Europe and shows as well how valuable cooperation between researchers of different ethnic traditions is for a holistic approach to the genres of oral folk creation.

\section{REFERENCES CITED}

ANAGNOSTAKIS, Nikolaos

1932-1933 To Phos, E'. ar. 11, 4. http://repository.kentrolaografias.gr/xmlui/ handle/20.500.11853/292470 (accessed November 6, 2019).

BASCOM, William

1965 The Forms of Folklore: Prose Narratives. Journal of American Folklore 78:3-20.

CAMPBell, Joseph

1988 The Power of Myth. New York: Doubleday.

Christodoulakis, Stavros

2011 Gities, Laiki therapephtiki tis Kritis [Charms. Folk Medicine in Crete]. Athina: Mpatsioulas.

Foley, John Miles

1991 Immanent Art. From Structure to Meaning in Traditional Oral Epic. Indiana: Bloomington University Press.

1992 Word-Power, Performance, and Tradition. Journal of American Folklore 105:275-301.

2005 Fieldwork on Homer. In Amodio, Mark C. (ed.) New Directions in Oral Theory: Essays on Ancient and Medieval Literatures, 15-41. Arizona: Tempe.

FRANKFURTER, David

1995 Narrating Power: The Theory and Practice of the Magical Historiola in Magical Spells. In Meyer, Marvin - Mirecki, Paul (eds.) Ancient Magic and Ritual Power, 457-475. Leiden: Brill.

HERZFELD, Michael

1981 An Indigenous Theory of Meaning and Its Elicitation in Performative Context. Semiotica 34(1/2):113-141.

HILLERS, Barbara

[2019]Towards a Typology of European Narrative Charms in Irish Oral Tradition. In CAREY, John - GeAlBháin, Ciarán Ó. - TuOMI, Ilona - Hillers, Barbara (eds.) Charms, Charmers and Charming in Ireland: From the Medieval to the Modern, 79-102. Cardiff: University of Wales Press. 
IONAS, Ioannis

2007 Gities. Soma Kypriakon epodon [Charms. Corpus of Cypriot Incantations], tom. A' \& B'. Lefkosia: Kentro Epistimonikon Erevnon Kyprou.

Kontomichis, Pantazis

1985 I laiki iatriki sti Lefkada [Folk Medicine in Leukada]. Athena: Ekdosis Gregori.

LENAKAKIS, Andreas.

2007 Magikes epodoi kai katadesmoi sti Mesara, iti githies, desimata ki enas magikos kodikas grammenos sti Messara to 1906 [Incantations and Binding Spells in Mesara, Charms, Binding Spells and a Magical Codex Written in 1906]. Mesaritika Laographika 2. Symboli sti Kritiki Paradosi. Iraklio: Antilalos.

LOUKAS, Georgios

1974 Philologikai episkepseis ton en to vio ton neoteron kyprion mnimion ton arxeon [Philological Reflections on the Survived Elements of Ancient Greece in the Life of Modern Cypriots]. En Athines: Ek tou typographiou Nikolaou Rousoupoulou. (1874 Phototipiki anatiposi, Kypriologiki Bibliothiki 2, Lefkosia).

LUDWIG, Theodore

1987 Incantation. In Eliade, Mircea (ed.) The Encyclopedia of Religion, vol. 7, 147-152. New York - London: Macmillan Publishing Company.

MALINOWSKI, Bronislaw

1954 Magic. Science and Religion and Other Essays. Garden City, NY: Doubleday Anchor Books. (1925 $\left.5^{\text {st }}\right)$

1965 The Language of Magic and Gardening, Coral Garden and Their Magic, vol. II. Bloomington: Indiana University Press. (1935 ${ }^{\text {st }}$ )

NADEL, Siegfried Frederick

1968 Malinowski on Magic and Religion. In FirTH, Raymond (ed.) Man and Culture. An Evaluation of the Work of Bronislaw Malinowski, 189-208. London: Routledge \& Kegan Paul. (1957)

OHRT, Ferdinand

1935-1936 Segen. In HofFman-Krayer, Eduard - Bächtold-StÄUbli, Hanns (Hrsg.) Handwörterbuch des deutschen Aberglaubens, Band VII., 1582-1620. Berlin - Leipzig: Walter de Gruyter \& Co.

Passalis, Haralampos

2011a Myth and Greek Narrative Charms: Analogy and Fluidity. In Mikhailova, Tatyana A. - Roper, Jonathan - Toporkov, Andrey L. - Nikolayev, Dmitry S. (eds.) Oral Charms in Structural and Comparative Light. Proceedings of the Conference of the International Society for Folk Narrative Research (ISFNR), Committee on Charms, Charmers and Charming, 43-49. Moscow: Probel.

2011b Secrecy and Ritual Restrictions on Verbal Charms Transmission in Greek Traditional Culture. Incantatio 1:7-24.

2014 From Written to Oral Tradition: Survival and Transformation of St. Sisinnius Prayer in Oral Greek Charms. Incantatio 4:111-138.

2016 Neoellinikes epodes. I dinami tou arritou logou stin elliniki laiki paradosi [Modern Greek Charms. The Power of Unspoken Speech in Greek Folk Tradition]. Thessaloniki: Rome. 
PhilipPOU, Loizos

1912-1913 Epodai kai katadesmoi ek Parou [Incantations and Binding Spells from Pócs, Éva Paros]. Laographia, $\Delta^{\prime}$, 527-536.

2014 Ráolvasások. Gyüjtemény a legújabb korból (1851-2012) [Charms. Collection from the Modern Period (1851-2012)]. Budapest: Balassi.

Politis, Nikolaos

1931 Ai astheniai kata tous mythous tou ellinikou laou [Diseases According the Legends of Greek People]. Laographika Symmikta III', [Dimosievmata tou Laographikou Arxiou, ar.], En Athines, 64-100.

Rousias, Georgios

1912-1913 Epodai Ksirochoriou [Incantations of Ksirochori]. Laographia, $\Delta^{\prime}, 46-52$. SPYRIDAKIS, Georgios

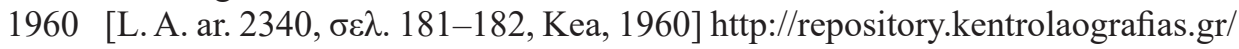
xmlui/handle/20.500.11853/292441 (accessed November 6, 2019).

STELlas, Zacharias

2004 Tis Paros, zougrafies atsoumpales: 7 aithies kai alla laographika kai glossika [Clumsy/Blowsy Paintings of Paros: Charms and Other Linguistic and Folk

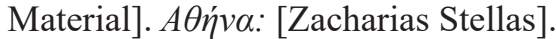

VicHOs, Konstantinos

1960 [MILOS, L. A. ar. 2339, 181-182]. http://repository.kentrolaografias.gr/xmlui/ handle/20.500.11853/292468 (accessed November 6, 2019).

VLACHOU, Alexandra

1959 Megarika ithoi kai ethima [Manners and Customs from Megara]. Laographia, $\mathrm{IH}^{\prime}$, 543-550.

Dr. Haralampos Passalis is currently employed as guest lecturer at University of Amsterdam in the department of Modern Greek Studies and as teacher of Modern Greek language in the Greek School Athena (Amsterdam). He is also external researcher at the Centre for the Greek Language-Department of Greek Medieval Lexicography (Thessaloniki) and member of the compiling team for the Dictionary of Medieval Vernacular Greek Literature 1100-1669, published by the Centre for the Greek Language. His personal research interests mainly focus on verbal charms (he is member of the International Society for Folk Narrative Research, Committee on Charms, Charmers and Charming), folk literature and vernacular religion in traditional Greek culture. Among his main publications is the book on Greek verbal charms: Neoellinikes epodes. I dinami tou arritou logou stin elliniki laiki paradosi [Modern Greek Charms. The Power of Unspoken Speech in Greek Folk Tradition], 2016. E-mail: harapass168@gmail.com

Open Access. This is an open-access article distributed under the terms of the Creative Commons Attribution-NonCommercial 4.0 International License (https://creativecommons.org/licenses/ by-nc/4.0/), which permits unrestricted use, distribution, and reproduction in any medium for noncommercial purposes, provided the original author and source are credited, a link to the CC License is provided, and changes - if any - are indicated. 


\section{Verbal Charms and Belief Narratives: Comparative Aspect}


